\title{
A Case History Of Electrical And Musical Industries (EMI)
}

\author{
Kenneth A. Hunt, Ph. D., Fort Lewis College, USA \\ Lech Usinowicz, Bayfield Elementary School, Bayfield, Colorado, USA
}

\begin{abstract}
Electrical and Music Industries (EMI) has been a leader in the music industry for almost eighty years. Indeed, the predecessor companies precede EMI by an additional twenty years. Remaining in a leadership position for so long requires leadership, foresight, and a good deal of luck. The following case reviews the history of EMI from 1931 to the present. As a case study, one can learn how adaptation and planning can lead to continuing success.
\end{abstract}

Keywords: Case, Music Industry, History of Music Industry, Electric and Musical Industries, EMI.

THE GREAT DEPRESSION - 1931 - 1939

$\mathscr{I}$ n 1931, in response to the economic impact of the Great Depression of the music industry, Colombia Graphophone Company Ltd. and Gramophone Company merged to form Electrical and Musical Industries (EMI) ("1930 - 1949"). The newly formed company included "FrŠres in France, Carl Lindstrom and Electrola in Germany, Columbia Nipponophone in Japan, Orient and the China Record Co. in China, GramCo in India and the Odeon and Parlophone labels of the Transoceanic Trading Company (a Dutch company formed to look after interests of German labels overseas during WWI); also subsidiaries in Australia, Italy, Spain, Romania and South America: 50 factories in 19 countries" (Clarke). As a result of the merger virtually every major artist in the world was represented by EMI or one of their other labels. At this time the only major recording companies not controlled by EMI were Decca UK, Brunswick USA, and the former Gramophone subsidiary Deutsche Grammophon Gesellschaft (DGG) in Germany (Clarke). At the time of the merger the Gramophone Company had $43 \%$ of total sales revenue going to the United States. American interests made up $80 \%$ of the Colombia Graphophone Company's total sales revenue (Sadie, Vol.8, p.182). Obviously both companies were major players in the record trade around the world (Sadie, Vol.8, p.182). Considering how much of an impact American interests had on each company before the merger it comes as no surprise that as a result of the Great Depression, beginning in 1931 sales dropped by one half between 1931 and 1934 (Sadie, Vol.8, p.182).

The Gramophone Company's artist roster included English composer Sir Edward Elgar, Arturo Toscanini, a composer and scholar from the Conservatory of Parma, professor and scholar Wilhelm Furtwanglar from Berlin, and Sir Thomas Beecham, a wealthy scholar who came back to his homeland after spending a period of time in London to form the London Philharmonic ("Parma - Arturo Toscanini") (Liu) ("Beecham Thomas"). In November of 1931, chairman Sir Louis Sterling and Elgar Beecham opened Abby Road Studios in North London, resulting in the first "purpose built" recording studio in the United Kingdom (Sadie, Vol.8, p.183). In 1932, 16 year old protégée Yehudi Menuhin recorded "One of the twentieth century's greatest recordings." (Sadie, Vol.8, p.183). In 1939, at the end of the Great Depression, 80\% of households had a radio (Sadie, Vol.8, p.183). This had a dramatic affect on record sales for EMI as the company observed an $80 \%$ drop in sales, selling only six million records over the ten year span between 1929 and 1939 ("1930 - 1949"). Similar to the dramatic decrease in sales that Victor encountered in 1924, EMI was forced to liquidate many of their records that were not being sold and in some cases delete many of the songs from their archives. Many artists were released at this time. The HMV ("His Master's Voice) catalog sold far more classical records than the Columbia owned classical label. Thus Columbia significantly discounted the distribution of these records (Sadie, Vol.8, p.183). In addition to the increased prevalence of radios in the home, many sales were lost because many of the products that were beginning to reach the market were made for comfort. However, the Rockefeller Center, or in other words "the huge city within a 
city," commenced the first stages of production which eventually lead to an RCA and NBC network studios and thus the birth of the radio age. (Lyons) In 1939 Sarnoff premiered television at the World's Fair in New York City. However with World War II threatening, the resources allocated to this new development were redirected to war efforts. ("Radio Corporation of America@Everything2.com.").

Between 1930 and 1949, Alan Blumlein, a research and development scientist for EMI's Columbia division, developed the world's first process used to successfully record and play in stereo. However due to the state of the market, this technology would not be commercially implemented for another 25 years. Blumlein made other remarkable developments as well, through the development of television in the EMI laboratories, thus permitting the UK to be the first country in the world with public television service. Of all of his developments and discoveries none would prove to be of greater use then radar used heavily in World War II ("1930 - 1949").

\section{WORLD WAR II: (1939 - 1945)}

As greater tension began to emerge leading up to World War II, a significant number of artists fled to America. EMI was supplemented by American licensers RCA Victor and American Columbia. Because of this migration of artists to America, American artists controlled the British popular music market. In 1945 Australian Sir Ernest Fisk was appointed managing director of EMI and after the war signed all of the greatest classical artists and 45 conductors (Clarke). Fisk saw very little value for the "long playing record" and focusing rather on the speed of record play. As a result many of the top artists at the time moved to Decca Records. American Columbia (RCA and CBS) saw insufficient organization under Fisk's direction and sought new licensures, CBS to Phillips in 1952 and RCA to Decca in 1953. EMI lost all representation in the United States as well as successful Croatian-American pop singer, Guy Mitchell.

\section{RECONSTRUCTION:}

In 1951 Fisk was removed from his position as managing director, though problems remained until Joseph Lockwood a flour milling engineer took over in 1954. Lockwood had experience operating worldwide subsidiaries of UK companies and recognized that the pop market had far more profit potential than that of the classical genre. He reconfigured the direction of the company and expanded into TV and films (Clarke). In 1946, just after the war was over, EMI hired Walter Legge, one of the world's great classical producers (Clarke).

Legge and Bicknell were hired to regain control of American interests and the British popular music scene. Together they formed Philharmonica, the House Orchestra for EMI. Bicknell then signed Austrian and German Artists: Edwin Fischer and Willhelm Backhaus, Dinu Lipatti, Elisabeth Schwarzkopf, Wilhelm Futwangler, Herbert Von Karajan, and Vienna Philharmonic Orchestra. Italian Artists: Tito Gobbi, and violinist, Gioconda Di Vito were also acquired at this time. EMI knew that they needed to regain control of their native consumer base, so in 1940 EMI hired managers to find and promote the best of British popular music. The managers included: Walter Ridley, Norrie Paramour, Norman Newall, and George Martin. Early Signings included: Josef Locke, Shirley Bassey, Donald Peers, Eartha Kitt, and Ruby Murray. Some of the orchestra-related acquisitions at this time included: Joe Hoss, Victor Sylvester, and Edith Pief (Sadie, Vol.8, p.184).

In the 1950's RCA Victor, a derivative of American Columbia Graphophone, and licensee of EMI, released "Heartbreak Hotel," Elvis Presley's first single outside of the United States on EMI's HMV label. EMI continued to expose the U.K. to Presley's Mississippi twang which at first was not received well, but eventually made it to the charts with "Blue Suede Shoes," "Love me Tender," "Hound Dog" and his big hit that topped the charts at number one, "All Shook Up." ("1950 - 1959").

In 1952, American Columbia ended their licensing agreement with EMI ("1950 - 1959"). With the threat of EMI losing all representation in the United States, EMI bought Capitol Records for 8.5 million dollars in 1955 (Schoenherr, "Capitol Records"). Considered one of the "Big Six" and the fourth largest record company in the United States, Capitol Records represented artists: Nat King Cole, Stan Kenton, Peggy Lee, Dean Martin, the self proclaimed "King of Jazz" Paul Whiteman (Considered the most popular band in the 1920's), and Frank Sinatra who made a total of 19 albums with Capitol between 1954-62 ("Paul Whiteman and his Orchestra")(Schoenherr, 
"Capitol Records"). Despite a considerable amount of disapproval for Lockwood for having paid so much for the merger he remained committed to the decision, which proved to be a great success. By 1959, Capital Records' worth had increased 10 fold to an estimated 85 million dollars (Clarke). In 1957, RCA too left EMI and established their own office in London ("1950 - 1959.") The other big players in the British rock scene were Adam Faith, Shirley Bassey, Frankie Vaughan, Max Bygraves, Alma Cogan, Helen Shapiro, and Cliff Richard (Schoenherr, "Capitol Records") ("1950 - 1959"). In 1958, Cliff Richard joined EMI and eventually went on to produce a total of 100 United Kingdom chart entries over the thirty years with the company (Clarke). These acquisitions by EMI resulted in a shift of talent back to the U.K. and out of the United States. EMI talent now accounted for 40\% of the United Kingdom Pop Music chart ("1950 - 1959").

The predominantly American artist music buzz officially ended in 1963 when Billboard published their annual best selling list based on the chart of 34 countries. The top four were Richard, Elvis Presley, The Shadows (Richard's backup group), and Frank Ifield. Ifield had signed with EMI records in 1959 and made his first British hit just one year later with Lucky Devil. He remained on the charts in the years that followed with hits like "I Remember You", "Lovesick Blues", "Nobody’s Darling But Mine", "Confessin"”, and his signature song "Waltzing Matilda" ("Frank Ifield - BIOGRAPHY"). All of the artists at the top if this list, with the exception of Presley, shared the EMI/Columbia label in addition to sharing Peter Gormler as manager, Frank Jarratt as their agent, and Norrie Paramour as their producer (Clarke). Listed at number seven on the list was the emerging group from Liverpool, the Beatles. By the middle of the 1960's EMI had the Beatles, Cilla Black, the Hollies, Billy J. Kramer (all on Parlophone); Richard, the Shadows, Ifield, Gerry and the Pacemakers, the Dave Clark Five, Peter and Gordon, the Animals, Herman's Hermits, Georgie Fame, the Yardbirds, the Seekers (all on Columbia UK), Manfred Mann (on HMV), Joe Cocker and the Move (on Regal-Zonophone) and the Beach Boys on Capitol Records. Between 1963 and 1964 EMI artists dominated the UK Charts with number one hits for 76 weeks straight. However this success was not seen in the United States. Many argue that this was because Capitol Records passed on nearly all of the artists including the Beatles. During this time 15 of the major EMI artists were on the charts in the United States however just three of them were signed by Capitol Records. (Clarke).

"If the 1950s saw British pop music grow, in the 1960s it exploded. And EMI was right at the forefront" ("1960 - 1969").

\section{THE BEATLES}

After being rejected by Decca, Phillips, Pye, and EMI itself in 1962, Brian Epstein, retailer and manager of Merseyside pop musicians in Liverpool, met with George Martin head of A\&R for EMI- Parlophone and big name producer of classical, jazz, pop and humor recordings for the EMI label group, who worked closely with Peter Sellers, Spike Mulligan, Dudley Moore, Stan Getz, Judy Garland, Tommy Steele, and Cleo Laine. Upon introduction to the group, Martin signed the Beatles (Sadie, Vol.8, p.184). Later that year, at the request of Martin, Pete Best was replaced by Ringo Starr who had previously been drumming with Rory Storm and the Hurricanes. The Beatles released their first single, "Love Me Do/P.S. I Love You," landed in the top twenty in the U.K. and their next single, "Please Please Me," reached number two on the charts, officially spawning what is then and now known as "Beatlemania". In 1963 the Beatles reached the top of the charts with four consecutive singles, "From Me to You," "She Loves You," "I Want to Hold Your Hand," and "Can't Buy Me Love" giving them the title of "Number One Group of the Year" in the "1963 New Musical Express" Twelfth Annual International Popularity Poll" and also voting the Beatles album "She Loves You" album of the year." ("The Beatles") (Crouse). "I Want to Hold your Hand" later became the fastest selling British single in history selling a half a million records in just 10 days ("History of the Beatles, Year by Year - 1964").

The Beatles truly crossed over any demographics with the compositions headed by Paul McCartney and John Lennon, who were cited by Richard Buckle, a classical music critic from the London Sunday Times, as "the greatest composers since Beethoven" ("The Beatles"). This assertion came just after the London Times had proclaimed these men as "The Outstanding Composers of 1963" (Crouse). On February 7, 1964 the Beatles arrived in America following the release of their first single in the U.S. "I Want to Hold Your Hand" released by Capitol Records on December 1, 1963. Their arrival was huge as they began their tour at the Coliseum in Washington, D.C., and on February 9, 1963 appeared for the first time on the Ed Sullivan Show. In 1964 the Beatles achieved a 
feat that perhaps no other band in history will ever accomplish by occupying all of the top five spots on the Billboard's Top Pop Singles chart with "Can't Buy Me Love" at Number One. They continued to increase their popularity with the release of their documentary film "A Hard Day's Night" in August 1964 ("The Beatles").

In the United States the Beatles eventually tallied a total of 20 number one singles, exceeding the impressive 17 number one hits produced by the American "King," Elvis Presley.

The Beatles were not only innovative in their compositions but also in the studio. In 1967 they released the "Sgt. Pepper's Lonely Hearts Club Band" album. This album was truly the first of its kind. Not only was "Sgt. Pepper's Lonely Hearts Club Band" the first time that multi-track recording had ever been used (Sadie, Vol.8, p.184) this was also the first time that any major artist had made an album with the intention of taking the listener on a musical quest from start to finish. This album "broke the mold in that no singles were released from it ("The Beatles"). This is just one of many reasons that the Beatles accounted for $20 \%$ of EMI's total sales at one point (Sadie, Vol.8, p.184). In 1988 the Beatles were inducted into the Rock and Roll Hall of Fame.

Epstein was responsible for bringing more than just the Beatles. Epstein introduced Billy J Kramer and the Dakotas, Cilla Black, and Gerry and the Peacemakers to EMI. The bands that managers would seek out would be specific to a single demographic. EMI acquired a number of bands for the next generation like the Hollies, Pink Floyd, and Queen (Sadie, Vol.8, p.184).

While the Beatles were making their buzz around the world, Capitol Records went in search of America's top talent and signed what would later become one of America's most prosperous bands of all time, The Beach Boys in 1962. The hits that assisted them in making it to the top were, "Surfin' USA," "I Get Around", "California Girls" and, their greatest hit, "Good Vibrations" ("1960 - 1969").

It was also at this time that EMI made a license deal with a new record label in Detroit called Tamla Motown, that had an impressive list of artists including Marvin Gaye, Stevie Wonder, Diana Ross and the Supremes, the Jackson Five, The Temptations, and Smokey Robinson to name the big ones ("1960 - 1969").

\section{0 - PRESENT:}

In the 1970's management fell under the new leadership of former head of the Gramophone Company of India, Bhaskar Menon, ("1970 - 1979"). The new management took on alternative business ventures including cinema and medical technology. Though just like the typewriter and electric clock, these alternative ventures failed (Sadie, Vol.8, p.185). One area that they were able to adapt was the emergence of 'progressive' rock. New artists that were acquired during this time included Deep Purple, Roy Harper, the Edgar Broughton Band, the Electric Light Orchestra, Pink Floyd, and Queen. Perhaps in an effort to preserve their reputation, EMI released many of progressive artists under its new label "Harvest" dedicated to the emerging "underground style of music" ("1970 1979").

Originally a rhythm and blues cover band called the Sigma 6 and the Architectural Abdabs, Pink Floyd eventually settled on the name and in 1967 signed with EMI. Headed by guitarist and vocalist Syd Barrett, Pink Floyd released their first hit single on the British singles chart: "Arnold Layne," recorded at Sound Techniques Studio in London and "See Emily Play" ("Pink Floyd"). The hit album, "Piper at the Gates of Dawn" was released at this time and is Pink Floyd's only album with Barrett as the front man ("1970 - 1979"). Due to his mental instability as a result of his extensive use of LSD, Barrett was replaced by David Gilmour who joined Roger Waters, Nick Mason and Rick Wright, that together went on to become one of the most successful bands in rock and roll history ("Pink Floyd") ("1970 - 1979").

Pink Floyd's 1973 album "Dark Side of the Moon" was undoubtedly their most popular album ever, remaining on the U.K. charts for six years and on the Billboard charts for 741 weeks (over 14 years), a record that still is seemingly untouchable ("Pink Floyd"). To date, over 35 million copies have been sold worldwide. Other influential and greatly successful albums included "The Wall," "Wish You Were Here," "Animals," and "A 
Momentary Lapse of Reason" ("1970 - 1979"). On January 16, 1996, Pink Floyd was inducted into the Rock and Roll Hall of Fame ("Pink Floyd").

In 1972, just one year before the release of Pink Floyd's "Dark Side of the Moon," Queen signed with EMI. Band members, Freddie Mercury, Brian May, Roger Taylor and John Deacon quickly defined themselves as the one-of-a-kind band with their elaborate compositions and great live shows ("1970 - 1979"). On March 19, 2001, Queen was inducted into the Rock and Roll Hall of Fame ("Queen"). p.185).

After an unruly appearance on television in 1974, the Sex Pistols were dropped from EMI (Sadie, Vol.8,

In 1977, EMI signed the Rolling Stones who would also later define themselves as one of the most successful bands in rock and roll history and, under representation of EMI, released albums, "Some Girls," "Emotional Rescue," and "Tattoo You" ("1970 - 1979"). In the 1980's the Stones left EMI and by the end of the decade, had signed with EMI's subsidiary Virgin Records. In 1989 the Rolling Stones were inducted into the Rock and Roll Hall of Fame ("The Rolling Stones").

In 1976, EMI, in a settlement with Hollywood studio Columbia Pictures, purchased Screen Gems and Colgems libraries thus resulting in the company's first major presence in the film music industry ("1970 - 1979"). In addition to EMI moving into the new venture of film music, and the 70's proving to be an amazing time of acquisitions of artists that have forever left their proverbial fingerprint on the industry, at the end of the decade EMI bought US record label Liberty/United Artists. At the time of the merger Liberty/United Artists owned Blue Note Records whose catalog included jazz legends Miles Davis, Thelonious Monk, Bud Powell, Sonny Rollins, Horace Silver, Art Blakey and Clifford Brown ("1970 - 1979"). In1979 EMI was bought by Thorn Electrical Industries forming Thorn EMI which later acquired United Artist, Chrysalis Records (who represented artists of all musical genres that included, Jethro Tull, Blondie, Spandau Ballet and Sinead O'Connor), and Virgin Records (Sadie, Vol.8, p.185).

In the 1980's, EMI began to recognize the emergence of other styles of music as the disco era was coming to an end ("1980 - 1991"). The 80's brought to light, heavy metal through its dark and distorted sound, exemplified by EMI's own Deep Purple, Led Zeppelin and the London based band Iron Maiden ("1980 - 1991"). By the end of the 1980's with the acquisition of music publishing company, SBK Entertainment World, EMI was emerging as one of the top music companies in the world.

Other successful artists for Thorn EMI at the start of the 1980s included Kate Bush, who had joined EMI in 1977 after being spotted by Pink Floyd's David Gilmour. Sheena Easton, Thomas Dolby and Duran Duran were also some of the leading lights of a new British musical invasion that swept into the US (Sadie, Vol.8, p.185).

In 1985 a new management team was hired to focus on the core of the business headed by James Fifield in 1988 (rental, retail, music, etc.). The new team brought in The Pet Shop Boys, Simon Rattle, Ruger Norrington, Nigel Kennedy, Roberto Alagna, Eternal, Blur, and Radiohead. As significant as Thorn EMI's marketing strategies had been up until now, none was as significant as the merger to come.

Then in 1992, Thorn EMI bought the largest independent music company in the world at the time from entrepreneur Richard Branson, the Virgin Music Group ("1980 - 1991"). The 960 million dollar deal included Virgin Music Group artists Janet Jackson, Lenny Kravitz, Peter Gabriel, the Smashing Pumpkins, Phil Collins, Paula Abdul, Simple Minds, Belinda Carlysle, Boy George, Soul II Soul, UB40, Steve Winwood, Massive Attack and, returning to EMI, the Rolling Stones. The deal also put Thorn EMI into the top three companies that controlled majority market share in the music industry. Thorn EMI joined Polygram and the Warner Music Group. Fifield, President of EMI Music, believed that the acquisition would save the company at least 34 million dollars per year by producing and distributing the former Virgin Music Group's artists. As managing director, Fifield increased the market share of Thorn EMI 3 percent (from10.8 percent to 13.8 percent) by focusing on the growth of the structural integrity of the business instead of acquisitions, "attract better employees, get more presence with the retail community" said Fifield. (Fabrikant). 
On August 29, 1996 EMI emerged from Thorn Electrical Industries resulting in EMI becoming arguably the largest independent record company in the world, controlling $15 \%$ of the total world market (Sadie, Vol.8, p.185). In 1997 in an effort to capture more the U.S. market that had slipped to just 8 percent, EMI purchased 50 percent of rap labels, Priority Records with artists, Snoop Dogg, Chingy, Ice Cube and NWA and 49 percent of Matador Records, and the largest independent Christian music label Forefront Communications with leading Christian artist DC Talk ("EMI Group plc -- Company History") ("1980 - 1991").

EMI continued to capture successful record labels and catalogs at this time by acquiring the leading independent label in Germany, "Intercord," and in 1997, EMI purchased 50 percent of the Jobete music publishing Motown catalogue of the 60's and 70's originally founded by Berry Gordy for 132 million dollars (Clarke). The catalogue includes "over 15,000 classic Motown songs including: "I Heard it through the Grapevine," "My Girl”, "I Just Called To Say I Love You" and "I'll Be There" ("1980 - 1991"). The remaining shares of the catalog were purchased in 2003 and 2004 for an additional 250 million dollars. However these recordings are currently owned by Universal Group subsidiary, Polygram. (Clarke). In 1999, EMI Music Publishing continued to develop its archives by acquiring a bulk of the stakes in the United Kingdom's Hit and Run as well as the Windswept Pacific catalogue that contained the copyrights to over 40,000 songs ("1980 - 1991").

EMI continued its stronghold on British pop music by signing the U.K.'s most successful group of the 1990's, the Spice Girls as well as hit artist Robbie Williams ("1980 - 1991"). The Spice Girls reached the top of the charts in 31 countries selling 35 million albums and 25 million singles. This surge in British popular music in addition to HMV's expansions around the globe, EMI quickly became the leading record, company in the United Kingdom, and the largest music publisher in the world (Clarke).

Considering that EMI is a strong advocate of promoting the arts and education in cultures and communities around the world, in 1991 they started a program that would measure the environmental impact of their operations around the world. As a result, almost all of EMI's electricity in the UK, and over 20 percent of their electrical needs around the world, are supplied from a renewable energy source ("1980 - 1991").

Leading up to the new millennium the emergence of digital music was becoming more and more prevalent in the music industry. However, EMI has always remained at the forefront of the technology trends and was quick to recognize and adapt to the coming era. By 1993 EMI had its first website and by 1998 a consumer could listen to a complete album on the internet (Mezzanine by Massive Attack). EMI continued to make themselves more accessible to their consumer through videos, and digital album downloads ("2000 - 2007").

By 2010, EMI expects one quarter of its total revenue to come from digital sales.

Other major acquisitions for EMI since the turn of the millennium were the Mute label with artists that included Moby, Depeche Mode, and Goldfrapp.

\section{EMI Annual Report - 2003 Pg. 34}

http://www.shareholder.com/visitors/dynamicdoc/document.cfm?documentid=392\&companyid=EMIL

Since the beginning EMI has recognized the demand for music around the world. Today the company operates in over 50 countries and represents over 1,300 recording artists around the globe ("2000 - 2007"). They have demonstrated their strong ability to maintain their dominance in the music industry through technological advances, acquisitions, and focused leadership.

\section{TEACHING NOTES}

This case study of EMI presents an excellent teaching opportunity to illustrate a number of marketing principles. Corporate leaders such as EMI must constantly reinvent itself. Perhaps no industry illustrates this basic principle as the music industry. Technological changes and changes in the tastes of the consuming public dictate that the music industry of today is not the music industry of yesterday, nor is it the same as the industry of tomorrow. EMI has been a leader in the industry from the time of $78 \mathrm{rpm}$ records, to 45 's to eight tracks, cassettes, 
cd's to today's mp3 technology. These technological changes require a leader such as EMI to innovate, and react to technological changes. In addition, the changes in musical taste requires that EMI recognize musical trends and talent that will appeal to those trend changes. Think about the number of changes that have taken place in the past seventy years plus. Big bands gave way to rock and roll, to the Beatles, punk, rap and hip hop. EMI not only survived, but lead the way for many of those changes.

The technological and popular taste changes isolated above, present an excellent opportunity to illustrate the practical importance of the product life cycle. This point can be illustrated by asking the students to describe the musical tastes of their grandparents, parents and their own tastes. Then a discussion of what the future holds for pop music. An interesting discussion should follow.

This case also presents an opportunity to discuss the importance of mergers and acquisitions. Below is a list of EMI subsidiaries. This case offers an opportunity to discuss the importance of mergers and acquisitions in accomplishing strategic corporate goals.

Finally, and possibly most importantly, this case offers the opportunity for the student to learn about an industry where the student already has some knowledge and interest. The student should easily relate to EMI. Perhaps this discussion could begin by asking "how many of you own an mp3 player." This could be expanded by asking "how many of your parents (and or grandparents) own an mp3 player." Since no case provides a learning experience without student interest and participation, this case should provide both.

Principal Subsidiaries: EMI Records Ltd.; EMI Music Publishing Ltd.; Capitol-EMI Music, Inc. (U.S.A.); EMI Entertainment World, Inc. (U.S.A.); EMI Music France S.A.; EMI Music Italy S.p.A.; EMI Electrola GmbH (Germany); EMI Music Australia Pty. Ltd.; Chrysalis Records Ltd.; Capitol Records, Inc. (U.S.A.); Virgin Records Ltd.; Virgin Records America, Inc. (U.S.A.); Virgin Schallplatten GmbH (Germany); Groupe Virgin Disques S.A. (France); Toshiba-EMI Ltd. (Japan; 55\%); EMI Group Home Electronics (UK) Ltd.; HMV Division; Dillons the Bookstore Division; EMI Group Finance plc; EMI Group North America Holdings, Inc. (U.S.A.); EMI Group North America, Inc. (U.S.A.); EMI Group International Holdings Ltd. (http://www.fundinguniverse.com/companyhistories/EMI-Group-plc-Company-History.html).

\section{AUTHOR INFORMATION}

Kenneth A. Hunt Ph.D. is a Professor of Marketing at Fort Lewis College, Durango, Colorado. Dr. Hunt received his Ph.D. in Marketing from Virginia Tech. He has published over forty articles in such Journals as: the Journal of Retailing, the Journal of the Academy of Marketing Science, and the Journal of Business Research.

Lech Usinowicz is a 2008 graduate of Fort Lewis College. Lech was a Music Business major at Fort Lewis. Lech is currently a music teacher at Bayfield Elementary School in Bayfield Colorado.

\section{WORKS CITED}

1. $\quad$ "1930 - 1949." EMI Group. 27 Nov. 2007 <http://www.emigroup.com/NR/exeres/BE7900F0-23FC-4EB4847A-23DBD9236A26.htm>.

2. $\quad$ "1950 - 1959." EMI Group. 27 Nov. 2007 〈http://www.emigroup.com/About/History/1950.htm〉.

3. $\quad$ "1960 - 1969." EMI Group. 27 Nov. 2007 <http://www.emigroup.com/NR/exeres/60E71CC3-405A-42F4A013-1B20496FAE04.htm>.

4. $\quad$ "1970 - 1979." EMI Group. 27 Nov. $2007<$ http://www.emigroup.com/About/History/1970.htm〉.

5. $\quad$ "1980 - 1991." EMI Group. 27 Nov. $2007<$ http://www.emigroup.com/About/History/1980.htm>.

6. $\quad$ "2000 - 2007." EMI Group. 27 Nov. 2007 <http://www.emigroup.com/About/History/2000.htm $>$.

7. $\quad$ "Beecham Thomas." Sir Beecham Thomas. 14 Oct. 2004. 27 Nov. 2007 <http://www.mauriceabravanel.com/beecham_thomas.html>.

8. $\quad$ Clarke, Donald . "EMI : MusicWeb Encyclopaedia of Popular Music." Classical Music CD and Concert Reviews - MusicWeb International. 27 Nov. $2007<$ http://www.musicwebinternational.com/encyclopaedia/e/E34.HTM>. 
9. $\quad$ Crouse, Richard. "Big Bang, Baby - Google Book Search." Google Book Search. 27 Nov. 2007 $<$ http://books.google.com/books?id=dYFv3ifE0f4C\&pg=PA99\&lpg=PA99\&dq=\%22the+greatest+compos ers+since+beethoven\%22+london+times\&source=web\&ots=pkJEU2sPvG\&sig=pJ0ARaHqnVz5X7FEzxi YBu8IiVM\#PPA99,M1\&gt;.

10. $\quad$ "EMI Group plc -- Company History." Connecting Angel Investors and Entrepreneurs. 27 Nov. 2007 <http://www.fundinguniverse.com/company-histories/EMI-Group-plc-Company-History.html>.

11. Fabrikant, Geraldine . " COMPANY NEWS; Thorn EMI Is Buying Virgin Music - New York Times." The New York Times - Breaking News, World News \& Multimedia. 7 Mar. 1992. 27 Nov. 2007 $<$ http://query.nytimes.com/gst/fullpage.html?res=9E0CE4D91238F934A35750C0A964958260\&sec=\&spo n=\&pagewanted $=2 \& g t ;$;

12. $\quad$ "Frank Ifield - BIOGRAPHY." Frank Ifield - the official site. 27 Nov. 2007 <http://www.frankifield.com/bio.html>.

13. "History of the Beatles, Year by Year - 1964." Beatles Worldsite: News and information about John Lennon, Paul McCartney, Ringo Starr, George Harrison, Beatle People, Beatles music \& lyrics, fanclubs, events, tours, conventions, history, birthdays,. 27 Nov. 2007 <http://www.beatles.ws/1964.htm>.

14. Liu , James C.S. . "Wilhelm Furtwangler." Welcome to MacConnect!. 20 Nov. 2005. 27 Nov. 2007 $<$ http://members.macconnect.com/users/j/jimbob/classical/furtwaengler.html $>$.

15. Lyons, Betty. "Victor Talking Machine Company." Historical Society of Haddonfield, New Jersey. 27 Nov. 2007 〈http://www.historicalsocietyofhaddonfield.org/VictorTalkingMachineCompany.htm>.

16. $\quad$ "Parma - Arturo Toscanini." Parma: the best of Parma.. 27 Nov. 2007 $<$ http://www.parmaitaly.com/toscaninik.html>.

17. $\quad$ "Paul Whiteman and his Orchestra." The Red Hot Jazz Archive. 27 Nov. 2007 <www.redhotjazz.com/pwo.html>.

18. $\quad$ "Pink Floyd." Rock and Roll Hall of Fame and Museum. 27 Nov. 2007 <http://www.rockhall.com/inductee/pink-floyd $>$.

19. $\quad$ "Queen." Rock and Roll Hall of Fame and Museum. 27 Nov. 2007 $<$ http://www.rockhall.com/inductee/queen>.

20. $\quad$ "Radio Corporation of America@Everything2.com." Welcome to Everything@Everything2.com. 27 Nov. 2007 〈http://everything2.com/index.pl?node=Radio\%20Corporation\%20of\%20America $>$.

21. Sadie, Stanley. New Grove Dictionary of Music \& Musician Volume 8. New York: Macmillan Publishers Limited, 2001.

22. Schoenherr, Steven E. . "Capitol Records ." History web pages. 27 Nov. 2007 $<$ http://history.sandiego.edu/gen/recording/studios2.html $>$.

23. "The Beatles." Rock and Roll Hall of Fame and Museum. 27 Nov. 2007 $<$ http://www.rockhall.com/inductee/the-beatles $>$.

24. "The Rolling Stones." Rock and Roll Hall of Fame and Museum. 27 Nov. 2007 <http://www.rockhall.com/inductee/the-rolling-stones>. 